\title{
AC 2012-3854: THE MIT LEWIS SURVEY: CREATING A BLUEPRINT FOR A COLD WAR TECHNOLOGICAL UNIVERSITY, 1947-1949
}

Dr. Atsushi Akera, Rensselaer Polytechnic Institute

Atsushi Akera is Associate Professor of history in the Department of Science and Technology Studies and the Director of First-year Studies at Rensselaer Polytechnic Institute. He has published Calculating a Natural World: Computers, Scientists and Engineers During the Rise of U.S. Cold War Research with MIT Press (2006) and is currently working on a book on the history of engineering education reform in the United States. 


\section{The MIT Lewis Survey: Creating a Cold War Blueprint for a Technological University, 1947-1949}

Amidst the structural changes and the "reengineering" of higher education, historical perspective can provide us with a vantage point from which to reflect upon the many changes we are seeing today. In my talk, I approach this opportunity through a study of MIT's Committee on Educational Survey, or the "Lewis Survey," whose 1949 report is regarded by many as the Cold War "blueprint" for MIT. Rooted in conversations that originated within our society, MIT faculty members embraced the notion of a broader and more fundamental approach to engineering education, even as they grappled with MIT's unique wartime experience.

Without question, the MIT administration, beginning with Karl Compton and James Killian, played a key role in MIT's postwar transformation. ${ }^{1}$ Yet it was the Lewis Survey that transformed MIT's organizational structure through its "Four School Plan," began the work of redefining the role of the faculty at a "technological university," and most importantly built a consensus among the faculty for a way forward. This paper looks closely at the intense efforts of the Lewis' committee - its members met no less than 119 times over the course of three yearsand how their views evolved in conversation with the MIT administration. Especially amidst present-day concerns about the erosion of shared governance at many U.S. colleges and universities, a historical study of the Lewis Survey provides one window into the advantages and limitations of a collaborative approach towards transformation.

\section{Background}

So let me start with a couple of point of general background:

- MIT was created in 1861 as a technical institution firmly grounded in the sciences.

- This being said, MIT stood somewhere within the spectrum of institutions that spanned the British and more analytical continental traditions in engineering education. ${ }^{2}$

- Industrial expansion during the late $19^{\text {th }}$ and early $20^{\text {th }}$ centuries drove the curriculum at MIT and elsewhere away from fundamentals. ${ }^{3}$

- It was in response to this, and to conversations within our own society, that the MIT Corporation hired Compton to place MIT back on a more scientific trajectory. ${ }^{4}$

Compton did in fact oversee many important changes at MIT, including the creation of the School of Science. This being said, MIT's transformation was uneven. Some departments, like Electrical Engineering fully embraced Compton's vision, while others remained more traditional. ${ }^{5}$

Compton also embraced the national vision for broad professional training found since the Wickenden Investigations. Active on the national scene, Compton spoke of the need, "if engineering is to be a true profession [that] it cannot be restricted to a plane surface of technical proficiency, but must embrace the third dimension of social responsibility and awareness." 6 This translated into a local decision to expand the "humanistic-social" program at MIT to eight subjects, or one course taken during each semester of a student's career. ${ }^{7}$ 
From the standpoint of MIT's history, the most significant consequence of Compton efforts was that it placed MIT squarely within the path of the U.S. science mobilization effort during World War II. As recounted on many occasions, MIT garnered a lion's share of the total OSRD wartime expenditures, a significant portion of which was dispersed across the institute.

\section{Origins of the Survey}

Various accounts make it clear that sponsored research was on the minds of many faculty at MIT. Still, as an indication of MIT's vestigial orientation towards being an undergraduate institution, there was almost no discussion about postwar research policies in the general faculty meetings. The main topic for discussion was the postwar enrollments surge, as exacerbated by the GI Bill. ${ }^{8}$

Insofar as the focus of my talk today is on shared governance, I will be focusing a lot on the process by which the faculty came to shape institutional policies at MIT. The idea to conduct "a long-range study of our entire educational policies and procedures," arose during the spring of 1946 in a conversation between Compton and the Chair of the Faculty, William H. Timbie.' Compton was concerned about the place of MIT's undergraduate program in MIT's future, and dedicated both his 1946 and 1947 annual reports to the question of undergraduate instruction. Skeptical of the move to "democratize" higher education, Compton suggested that MIT had to focus on delivering a superior type of education that was more expensive, but selective. ${ }^{10}$ While he held strong views on the subject, Compton proceeded to endorse Timbie's proposal to have the faculty deliberate on the issue. ${ }^{11}$

\section{Early Work}

Following a rather lengthy process of selecting committee members, Lewis' committee, shown here in this slide, met for the first time on 17 January 1947, devoting most of the first meeting to logistics. ${ }^{12}$

SLIDE 1: Membership of the Committee on Educational Survey

- Warren K. Lewis (chair of committee), founder of MIT's Chemical Engineering department.

- John R. Loofbourow, professor and Executive Officer of the Biology Department and the Secretary of the committee

- Ronald H. Robnett, professor of Engineering and Business Administration and a fiscal officer in the DIC (MIT's sponsored research office)

- C. Richard Soderberg, a theoretically oriented mechanical engineer and head of that department

- Julius Stratton, physicist and director of Research Laboratory for Electronics, the postwar incarnation of the Radiation Lab 
Among the other items the committee discussed was an unsolicited letter from the head of the Physics Department, John Slater, expressing his unabashed preference for a curriculum more solidly grounded in the sciences. ${ }^{13}$

Of equal importance at the first meeting was a conversation about the "problem of the representation of the humanities." During the nominations process, the ad hoc committee that was established for this purpose chose a step-by-step voting process that emphasized the prominence of its members. But given the service orientation of the Humanities Division, this ensured that no one from the division made the cut. Howard Bartlett, the head of the English and History Department, complained bitterly, given, in his view, the absurdity of a committee with no humanists deliberating on the breadth of technical education. ${ }^{14}$ Adding to the weight of Bartlett's remarks was the recent release of the Harvard University study, General Education in a Free Society, which was then receiving a good deal of national attention. ${ }^{15}$ The ironic consequence of the MIT faculty's decision to exclude the humanists was that it brought humanistic studies more directly into the fold of the reforms being contemplated for MIT.

The Harvard study influenced the Lewis Survey's ideas, but it also influenced its process. During the first meeting, Lewis' committee also decided to invite George Wald, a member of the Harvard study group, to talk about the "mechanics" of their investigation. Speaking at the Committee's third meeting, Wald described how the group had decided at the outset that they would begin by acquainting themselves with the issues, rather than moving quickly towards judgment. Following the customs at Harvard, this translated into a series of evening talks at the Harvard Faculty Club that were allowed to evolve into polite conversation. Wald noted that it was only upon reaching "the law of diminishing returns" that their study team set out to write their report, which was done at a "quiet place remote from Harvard."

This, in outline, was the procedure adopted by Lewis' committee. Lewis' committee also scheduled weekly meetings with invited speakers, and the intent, at least initially, was to conduct an open ended inquiry rather than honing too quickly in on key issues. The committee also went to a retreat in Andover, MA to write their report. Nevertheless, there were notable differences. The MIT group met for lunch, not dinner, owing in part to the fact that MIT did not have a faculty club - a point of contention for the faculty. There were also members of the committee, most notably Stratton, who felt ill-at-ease with Harvard's contemplative pace. Already by the fifth meeting the group was moving towards "crystallizing more definitely" the matters in which the committee should concern itself. By the twelfth meeting, the group was holding executive sessions in addition to the luncheon meetings. ${ }^{17}$

The most significant difference between the Harvard and MIT studies was that the MIT group looked inwards rather than outwards. While Lewis' committee was given tremendous latitude, being instructed simply to "determine the objectives and scope of the Survey, [and] the manner in which it shall be conducted," the faculty did encourage them to seek broad input, creating subsidiary committees as necessary. Lewis' committee wound up speaking primarily with their own administrators and faculty, apart from a handful of outside experts, in developing a course for MIT. ${ }^{18}$ Operating in the fashion of an investigative hearing, it was through this process of synthesizing ideas and practices that the committee wound up with a blueprint for MIT's future. 


\section{Positive Environmentalism}

In thinking how best to structure this talk in the time available, I thought it might be best to focus on the specific themes that emerged in the final report, but to also do this in a way that still draws attention to the process of faculty deliberation and shared governance.

So one of the issues that first came to the foreground was the question of "staff environment." This matter was initially brought up by Killian (then the Executive Vice President and special assistant to President Compton), but quickly caught the imagination of a faculty troubled by overloaded working conditions and the postwar year-round teaching schedule. This translated quickly into a concern about the "pace" of work, and how this was not conducive to the contemplative and reflective process necessary for truly creative scholarship. ${ }^{19}$ As suggested by Stratton midway into their investigation, "MIT is indeed a factory, set among other factories in industrial Cambridge; and the dispersed, industrial character of our living and environment clashes violently with our aspirations for scholarly creative achievement. Never has the Institute given proper attention to the significance of these facts." 20

Following a practice found more within engineering education and management circles, Lewis' committee put together a survey with which gather faculty attitudes. ${ }^{21}$ It also convened a separate Committee on Staff Environment, headed up by W. Rupert Maclaurin, an economics faculty member (and son of a former MIT President). ${ }^{22}$ This committee, throughout its year and a half of deliberations, embraced a positive environmentalist philosophy, grouping their recommendations around three "environmental" categories. The following chart provides a list of the major recommendations of the committee. ${ }^{23}$

SLIDE 2: Major Recommendations of the Committee on Staff Environment

Administrative

Environment

- Return to 9-month teaching schedules

- Salary to match top universities

- Governance. Faculty voice in major policy decisions

- A strengthened \& more selective tenure process $\underline{\text { Intellectual }}$

Environment

- Only have departments in which MIT excels

- All faculty as research active

- Recognizing first rate teaching

- Also a strengthened \& more selective tenure process
Physical

Environment

- 20 year campus master plan

- West campus as seat of campus life

- Facelift for aging classrooms

- New dormitories / residential instruction

- Seminar rooms

- Auditorium / galleries

- Faculty club (with residential facilities for visiting scholars) 
The positive environmentalism that guided the committee's thinking should be evident from many of the items on this list.

As also evident from this list, Maclaurin's committee found it difficult to keep their discussions focused on matters of staff environment alone. What they envisioned was the entire remaking of MIT into a more liberal academic institution designed to uplift the students and faculty like. As such, their discussions crossed over into the realm of undergraduate education, and the turf of the other subsidiary committee, the Committee on General Education, created by Lewis' committee. The clash between all three committees would contribute to the Lewis Survey's ideas about shared governance.

SLIDE 3: Kresge Auditorium and its adjoining chapel, both of which were designed by Eero Saarinen.

\section{General Education at a Technological University}

This other committee, the Committee on General Education, had a more complicated origin. The idea of a broadly liberal approach to engineering education had wide currency within the MIT, so that when Lewis' committee spoke with members of the administration, they found many proponents for a strong program in the humanities. ${ }^{24}$ This led Lewis' committee to John Burchard, the respected if also outspoken Director of Libraries who was seen as the likely successor as the Dean of the Humanities Division. Burchard recognized that it was unlikely that the MIT faculty would grant any further expansion in the humanities program. Drawing on developments elsewhere, Burchard suggested instead that the committee focus on promoting a more integrated, less tradition-bound curriculum that created more opportunity for faculty research and specialization. (This dovetailed with the Committee on Staff Environment's recommendations that all MIT faculty be engaged in research in the area in which they specialized). ${ }^{25}$

Lewis' committee first turned to Burchard for some nominees, but Burchard could only name members of the humanities and science faculty. ${ }^{26}$ It was while Lewis' committee was discussing how best to expand the engineering representation, that the Dean of Engineering, Thomas Sherwood, approached the Lewis' committee with his own ideas about how to broaden engineering education. Active on the national scene, Sherwood put forward an elective program for a "science-based liberal education curriculum" that would be built around equal exposure to technical and non-technical curricula. ${ }^{27}$ (This fit within prevailing conversations about developing a pre-engineering curriculum that favored engineering professionalization and specialization at the graduate level.) While not totally convinced of the viability of the specific proposal, the immediate reaction on the part of all members of Lewis' committee was that they had found the chair of the Committee on General Education. ${ }^{28}$

Sherwood graciously accepted the invitation. But while everyone seemed to agree on the general nature of the problem, the solution was anything but obvious. Resource limitations indicated that it would be difficult to convert the Humanities Division into a degree granting unit without 
posing a fiscal burden on the institute at a time when rapid growth, and MIT's still limited endowment, presented continuing fiscal pressures on the institute. A window into a possible solution arose during an early meeting between Killian and Lewis' committee, during which Killian mentioned, initially in the negative, that MIT should be a first-rate technological institute rather than a second-rate university. ${ }^{29}$ Despite Killian's assertion, Lewis' committee continued to ponder the implicit question of whether a further expansion into the sciences and humanities would make MIT something more like a "technological university." Compton, in a subsequent meeting, suggested, provocatively, that perhaps MIT had already achieved this status. ${ }^{30}$

Compton's remark gave Lewis' committee the confidence by which to begin exploring more definitely how they could envision their reform effort as creating a fundamental new identity for MIT. The term, "technological university" was clearly an oxymoron (although one used in Germany at least since 1946). Yet the tension within the phrase provided precisely the space necessary to consider a viable middle ground between a general university and an institution whose strengths lay with its technical curricula. Rhetorically, Lewis' committee began to speak more generally about a university with "limited objectives," a point of view that filtered into the conversations of its subsidiary committees. ${ }^{31}$

Yet although there was rapid consensus around the need to strengthen the humanistic training, or at least exposure, of all MIT students, there was little agreement on how best to do so. In the deliberations that followed, it was clear that the MIT faculty, whom they continued to survey, held at least three different attitudes:

- One set of views called for the closer integration of the humanities \& social sciences with scientific and engineering studies in a broadly utilitarian view of the humanities.

- Another group called for the humanities to be a means of personal uplift and a way for students to develop a meaningful "life philosophy."

- There were those, meanwhile, who expressed skepticism that the humanities were something that could be taught to engineering students. In a position that dovetailed with the positive environmentalism found elsewhere in the report, the proponents of this view called for a focus on extra-curricular activities, such as art exhibits, musical concerts, and theater performances. (This was also a philosophy that had been translated into practice by an MIT past president, Henry Pritchett, who used it to limit the number of humanities courses required for MIT students.) ${ }^{32}$

More subtle differences within the first position became manifested as a difference in the recommendations of the two subsidiary committees. Sherwood's committee followed the line of reasoning advanced by Burchard, namely that the Institute should create an integrated sequence of courses that would be more relevant to students, while also allowing the Humanities division to develop faculty strengths in specific sub-fields. ${ }^{33}$ Although working from a similar premise, Maclaurin's committee recommended instead that the current humanities program be absorbed into a new School of Human Relations that augmented the current English and History faculty, with new hires in Management and Economics. ${ }^{34}$ (Maclaurin's proposal was not an eclectic one. It built on a major pedagogic experiment at the Carnegie Institute of Technology. More importantly, a \$5 million donation from the Alfred P. Sloan Foundation would allow MIT to turn Maclaurin's idea into the highly successful Sloan School of Management (and Technology) in 
1952. The placement of MIT's Economics Department within the Sloan School of Management owes itself to Maclaurin's ideas and influence. $)^{35}$

\section{Sponsored Research and Graduate Education at MIT}

Sponsored research was meanwhile the 600 pound gorilla in the committee's deliberations. As contrasted against the wide-ranging conversations that occurred around general education, the Committee on Educational Survey's conversations about sponsored research had a much more specific focus, stemming from concerns about graduate student experience. On the table were two recent incidents in which a graduate student expressed some concern about undue influence on the direction of their theses. Given that there was already a standing faculty Committee on the Graduate School, chaired by John Bunker, Lewis' committee tasked Bunker with a full assessment of the situation and the associated "dangers" of sponsored research. ${ }^{36}$

Seeking to properly assess the situation, Bunker called a meeting of the directors of some of the largest MIT laboratories. Given the rumors that began circulating, these directors arrived to the meeting feeling that they had been called to the carpet. Wishing for a positive affirmation of their work, they pressed the Committee to acknowledge that sponsored research stood at the heart of what was contributing to MIT's postwar reputation, and its opportunity to elevate and remake the institution. $^{37}$

Whatever their position prior to this meeting, the committee shifted its stance towards weighing the "disadvantages and dangers" against the advantages of graduate work carried out under a sponsored research contract. The advantages and disadvantages as compiled by Bunker and his committee were as recorded in the slide (Slide 4 ) on the next page. ${ }^{38}$

In the end, Bunker's committee's position evolved into one where they felt that while many hypothetical evils could be conjured, the fears were easily exaggerated. They admitted that dangers existed, and that some caution was necessary, but felt that the matter could be left, with proper guidance, with the individual investigators.

This also became the position of the Committee on Educational Survey. More importantly, in construing the issue narrowly as a question of graduate education, Lewis' committee never asked the broad question about how sponsored research, as a whole, might change the character of MIT. In other words, the Lewis Survey played no defining role in this aspect of MIT's transition. Instead, the decision was made through the autonomous choices of MIT faculty who chose to embrace military research amidst the absence of a more definitive policy. In the words of one of the committee members, "Admitting all complications with sponsored research, we still regard it as the very lifeblood of the vitality and growth in our business." 39 The Committee on Educational Survey had in effect affirmed the arrangements that had very quickly become the de facto policy regarding sponsored research at MIT. ${ }^{40}$

\section{Institutional Structure and Writing the Report}

It was about a year into their study when Lewis' committee decided that they should begin to pull together their ideas into a coherent report. ${ }^{41}$ The specific impetus to do so arose out of a 


\section{SLIDE 4:}

Committee on Graduate School Assessment of the Advantages and Disadvantages of Sponsored Research

Advantages

- Research contracts render opportunities to render valuable public service, particularly in problems of national defense

- Contracts for basic research are desirable as means of building up [the] research atmosphere of the institute

- Research contracts... make it possible for members of the staff to carry out and supervise research

- Excellent thesis topics

- Financial aid for students

- Training opportunities not equaled in industry
Dangers and Disadvantages

- Inappropriate theses if not properly supervised

- Certain types of sponsored research may be more suitable for industrial organizations with which the educational institution should not compete

- Steer project in direction of funding agency interest

- If large, schools may become financially dependent and vulnerable to cancellations and sudden changes in the sponsors' plans

- Where equipment must be built and deadlines met, research activities might gravitate away from education and tend to become a business

- Larger funds may lead to paying men more to work on such labs... Raise academic salaries

- Drive to complete sponsored research project may lead the institution to assign staff members to it even thought these men might prefer teaching or other research activities.

conversation with a visiting professor, Lounsbury Fish, who was, by chance, studying MIT's administrative structure. While Fish's own observations about the administrative structure at MIT seemed to have little impact on the Lewis Survey, one remark that had a catalyzing effect was Fish's suggestion that it was important to always start by defining an institution's objectives, from which the organizational structure would follow. ${ }^{42}$

Often the first to lead the charge, it was Stratton who picked up on Fish's idea in a memo entitled, "Outline of a Working Program for the Committee on Educational Survey." Stratton suggested that the committee should shift its focus to defining the broad objectives of MIT (as opposed to objectives of the committee), and then to assess how their discussions to date fit 
within the overall plan. This would also help them assess the competing recommendations advanced by Sherwood and Maclaurin. ${ }^{43}$

The differences in the position taken by each committee member are instructive. Stratton's position revolved around the idea that MIT was already among the foremost technical schools of the world, and its task was to achieve "the final evolution into a very great institution."44 Robnett's view was that MIT ought to establish undisputed leadership in all four of its major fields, which for him consisted of science, engineering, architecture, and management. ${ }^{45}$ Soderberg, in drawing on a more Nietzschean perspective, saw MIT's task as that of producing "exceptional men," and from this, backed Maclaurin's committee's emphasis on staff environment. ${ }^{46}$

Loofbouow was more philosophical. Dwelling on the flip-side of the positive environmentalism that informed Soderberg's position, Loofbourow spoke of being troubled by the "spectacle of cities decaying from within," and various modern scientific developments including the atomic bomb, "a fear of which contributes to psychological unrest." In his view, technological progress, after making many positive contributions, had "gone on to make other aspects of the physical environment progressively more unpleasant." This meant that it was no longer sufficient for MIT to have as its objectives "the training of men for efficient and effective contribution to... practical pursuits. ... My thesis then, is that MIT's objectives should be to train men for a better more constructive life as well as for efficient technical or professional work." ${ }^{47}$ While Lewis also brought up similar themes related to urban and societal crises, his vision for MIT education was based on more conventional ideas about labor and industrial relations that dovetailed with Maclaurin's proposal. ${ }^{48}$

In order to come up with a final report, the committee needed to resolve their differences with regards to general education. ${ }^{49}$ Lewis' committee regarded Sherwood's liberal science proposal, as well as Maclaurin's Human Relations proposal to be eclectic and not entirely suited to the student needs at MIT. At first, the committee attempted to resolve the issue by negotiating with its subsidiary committees, but neither of these committees was willing to bend its position sufficiently. ${ }^{50} \mathrm{~A}$ break in the impasse occurred after Maclaurin transmitted his proposal directly to the administration, without Lewis' authorization. Fortunately, Compton weighed in with his own skepticism regarding the proposal (he did, however, forward it to the trustees). However, in the course of commenting on it, Compton acknowledged that the Humanities Division could be elevated to a status that, at least in principle, would be equivalent to the other schools. ${ }^{51}$

It was this remark that led Lewis' Committee to come up with the "Four School Plan," and through it, treat the question of general education as a structural issue, rather than a substantive problem for them to solve. In other words, the Four School Plan was much more than an idea simply to elevate the status of the Humanities Division. It embraced the idea that the humanities faculty at MIT ought to be research based; that the its faculty, and the division as a whole, should have greater autonomy; and most importantly, that the question of the proper focus for the general education program at MIT should emerge out of the autonomous deliberations of this group, and not through the deliberations of an institute-wide committee with a strong engineering or management representation. There were also other ideas that followed from the Four School Plan. One was a decision to vest greater responsibilities and power to the academic deans, who 
would be given the authority to review departmental tenure decisions and transfer funds across departmental lines. But this was then paired with a new conversation about the "unity of faculty" in which Lewis' committee asserted that both the schools and the Institute administration ought to remain accountable to the MIT faculty as a whole, which would deliberate on broad issues of policy. $^{52}$

This last point required a reworking of the faculty's own governance structure, which had the faculty serving on various "operational" committees that was a vestige of its technical institute origins. Smarting from the idea that they could not even work through the differences among their own subcommittees, Lewis' committee suggested that there ought to be a single, powerful Committee on Undergraduate Policy that would oversee other faculty committees on issues related to undergraduate instruction. While shying away from a more formal governance structure, such as a faculty senate - there were benefits to operating as a single, united bodyLewis' committee nevertheless called for a move away from the haphazard committee structures that blunted the faculty's capacity for making policy recommendations that could influence the administration. ${ }^{53}$

\section{Conclusions}

The "Report of the Committee on Educational Survey," or Lewis Survey, was delivered in December of 1949 to the faculty and to James Killian, who had stepped up to become MIT President in late 1948. The faculty voted at its next meeting to advance the report to the members of the MIT Corporation. Acceptance of the report did not mean acceptance of the individual recommendations, a point made clear during subsequent discussions. Nevertheless, the report as a whole was received enthusiastically by both the faculty and administration. ${ }^{54}$

In abbreviated form, the Lewis Survey perhaps provides us with the following lessons:

- The strength of shared governance does not necessarily lie with efficiency, not does the process always yield effective or coherent answers (as demonstrated by the eclectic proposals from Sherwood and Maclaurin's committees).

- Nevertheless, the deliberative processes of a faculty can produce a coherent and significant vision (one which, for MIT, served as an important institutional blueprint for the Cold War era).

- This vision relied on giving articulation to concepts such as a "technological university", "Four School Plan", and "unity of faculty" that served to rally the faculty and administration around a new institutional direction.

- In fact, one of the principal benefits of shared governance may be that it serves to enroll the faculty in a major institutional change - necessary changes that the administration may already be aware of, or at least substantially cognizant about. (Had the administration issued policy statements with very similar ideas, the faculty response may have been quite different.)

- The MIT administration entrusted the faculty to carry out these deliberations, this is not to say that the administration exerted no influence. Shared governance seems to work best when faculty committees consult with, and continue to acknowledge the realms in which the administration is regarded as having primary responsibility. 
- A study such as the Lewis Survey also proceeds by drawing prior practices of educational reform. The Lewis Survey drew eclectically from the methods employed in the Harvard study, the "survey" tradition in engineering education, the organizational advice of a management professor, and broader institutional traditions such as the general form of a investigative hearing, in order to formulate their solution. (At MIT, this hybrid process led to a more inward-directed study, as opposed Harvard's study, which emphasized external experts and expertise.)

- Finally, it is important to note that the success of the Lewis survey cannot be regarded as proof that shared governance works in every instance. It failed at other points in MIT's history. At most, the successes of the Lewis Survey indicate that shared governance can work, and can be a significant asset to an academic institution, under the right circumstances and with the right effort.

\section{Notes}

\footnotetext{
${ }^{1}$ Christophe Lecuyer, "The making of a science based technological university: Karl Compton, James Killian, and the reform of MIT," Historical Studies in the Physical Sciences 23 (1992): 153-180. For other historical accounts of MIT during this period and the foundational years preceding it, see John Servos, "The industrial relations of science: Chemical engineering at MIT 1900-1939," Isis 71 (1980): 531-549; Larry Owens, "MIT and the federal 'angel': Academic R\&D and federal-private cooperation before World War II," Isis 81 (1990): 188-213; Roger Geiger, To advance knowledge: The growth of American research universities (New York, 1986); Stuart W. Leslie, Cold War and American science: The military-industrial-academic complex at MIT and Stanford (New York, 1993); Henry Etzkowitz, MIT and the rise of entrepreneurial science (London, 2002).

${ }^{2}$ For an overview of the different American traditions, see Terry S. Reynolds, "The engineer in $19^{\text {th }}$-century America," in The engineer in America: A historical anthology from Technology and Culture (Chicago, 1991), 7-26.

${ }^{2}$ Charles Riborg Mann, A study of engineering education (New York, 1918); Society for the Promotion of Engineering Education, Report of the investigation of engineering education, 1923-1929, 2 volumes (Pittsburgh, 1930 \& 1934).

${ }^{3}$ Charles Riborg Mann, A study of engineering education (New York, 1918); Society for the Promotion of Engineering Education, Report of the investigation of engineering education, 1923-1929, 2 volumes (Pittsburgh, $1930 \& 1934)$.

${ }^{4}$ Lecuyer (n. 1 above).

${ }^{5}$ Lecuyer (n.1 above), 178-179.

${ }^{6}$ Atsushi Akera, "Liberal learning revisited: A historical examination of the reasons, frustrations, and continued prospects for engineering and liberal arts integration," American Society for Engineering Education Conference Proceedings, 2011 Annual Conference \& Exposition. Available at http://www.asee.org/search/proceedings (accessed 12/22/2011).

${ }^{7}$ R. G. Caldwell, "Humanities at M.I.T.," 30 November 1945. AC 20, Box 4/183. MIT Institute Archives and Special Collections, Cambridge, MA; MIT President's report, 1943-1944, 7. Hayden Library, MIT Libraries, Cambridge, MA.

${ }^{8}$ Ibid.

${ }^{9}$ Technically, the proposal was first presented during the Spring of 1946 before the Faculty Council, an administrative entity comprised of the President, Deans and Vice President, Chair of the Faculty, and Department Heads. It was then presented to the full faculty, for approval, at the start of the Fall semester. MIT President's report, 1945-1946, 11-12. Hayden Library, MIT Libraries.

${ }^{10}$ Ibid.

${ }^{11}$ Ibid., 1945-1946, 11-12.

12 "Faculty records," (minutes). 15 January 1947, 81. AC 1. MIT Institute Archives.

${ }^{13}$ Ibid.
} 
14 "Report Special Faculty Committee to Recommendation Organization and Personnel for a Faculty Survey of Education at M.I.T.," n.d.. in Committee on Educational Survey, "Minutes of meetings, Jan. 1947- Jan. 1950," bound minutes, Volume 1 (CES minutes)., 17 January and 3 February 1947.

${ }^{15}$ General education in a free society: Report of the Harvard committee (Cambridge, MA, 1950).

${ }^{16}$ CES minutes, 17 January and 11 February 1947.

${ }^{17}$ CES minutes, 25 February, 25 March, 2 April, and 27 October 1947.

${ }^{18}$ The faculty accepted the recommendations as outlined in "Report" (n. 25 above).

${ }^{19}$ CES minutes, 25 February 1947.

${ }^{20}$ Julius Stratton, "Outline of a working program for the Committee on Educational Survey," 3 November 1947. In CES minutes.

21 "Bulletin and questionnaire no. 1," 1 May 1947. In CES proceedings.

${ }^{22}$ CES minutes, 2 April, 30 April, 27 and 28 May 1947.

23 "Report of the Committee on Staff Environment," in Report of the Committee on Educational Survey ("Lewis

Survey") (Cambridge, MA, 1949), 139-145.

${ }^{24}$ CES minutes, 6 May 1947.

${ }^{25}$ John E. Burchard to Professor Loofbourow, 25 March 1947. In CES proceedings.

${ }^{26}$ CES minutes, 23 April 1947.

${ }^{27}$ Thomas K. Sherwood to W. K. Lewis, "Cultural background for engineers,” 29 April 1947. In CES minutes, 29 April 1947.

${ }_{28}^{28}$ CES minutes 13 May 1947.

${ }^{29}$ CES minutes, 11 March 1947.

${ }^{30}$ CES minutes, 1 July 1947.

${ }^{31}$ The evolution of the idea is captured in the multiple outlines and drafts, and is captured in the final report in Lewis Survey (n. 23 above), 38-39.

32 "Suggestions made in response to preliminary statement," n.d. in CES proceedings.

33 "Report of the Committee on General Education," in Lewis Survey (n. 23 above), 81-124.

34 "Proposal for an endowment for a Division of Human Relations at the Massachusetts Institute of Technology," attached to Killian to MIT Corporation, 18 August 1947. CES proceedings.

${ }^{35}$ CES minutes, 16 January and 23 January 1948; 27 May 1949. Lewis and Robnett supported Maclaurin's proposal to build the humanities program around the concept of "human relations," and to rechristen the division the Division of Human Relations, but the other three committees did not agree with this.

${ }^{36}$ CES minutes, 4 March 1947.

${ }^{37}$ J.W.M. Bunker to John Loofbourow, 17 July 1947. CES proceedings.

38 "Notes on sponsored research in engineering at MIT," 3 June 1947. In CES proceedings.

${ }^{39}$ Ibid.;

${ }^{40}$ Lewis Survey (n. 23 above), 49-64.

${ }^{41}$ John Loofbourow to Warren K. Lewis, "Some comments on the M.I.T. Educational Survey," memo, 14

November 1947. In CES minutes. Statements from the other committee members in response to Fish's suggestion are also filed within the minutes.

${ }^{42}$ Ibid.; CES minutes, 20 October 1947.

43 J. A. Stratton, "Outline of a working program for the Committee," 3 November 1947. In CES minutes.

${ }^{44}$ Ibid.

${ }^{45}$ R. H. Robnett, "Some comments for the Committee on Educational Survey," 10 November 1947. In CES minutes.

${ }^{46}$ C. Richard Soderberg, "Statement of objectives and aims," 10 November 1947. In CES minutes.

${ }^{47}$ Loffbourow, "Some comments," (n. 41 above).

${ }^{48}$ W. K. Lewis, no title, 19 November 1947. In CES minutes.

${ }^{49}$ CES minutes, 22 December 1947.

${ }^{50}$ The committee's initial reaction to the Committee on General Education's draft report, which was also transmitted directly to the administration, is documented in Committee to J. R. Killian, "Report of the Committee on General Education," 5 March 1948. In CES proceedings.

51 "Proposal for an endowment for a division of human relations," August 1947. In CES proceedings; Karl T. Compton to Members of the MIT Corporation, 18 August 1947. In CES proceedings.

${ }^{52}$ The idea of disciplinary parity was expressed as early as April of 1947 in a letter from the faculty (Joseph Keenan to W. K. Lewis, 10 April 1947). Concrete discussions about setting up the humanities division as a fourth school can be found beginning with CES minutes, 12 January 1948, and 1 March 1948; and appears in its final form in Lewis 
Survey (n. 23 above), 43-45; On the "unity of the faculty," the conversation began with J. A. Stratton, "Outline" (n. 20 above), and apparently attained full fruition only during a retreat in Andover in later 1949. "Discussions at Andover, September 28, 29, 30, 1949.” In CES minutes; Lewis Survey (n. 23 above), 10, 14, 15, 44, 66.

${ }^{53}$ The idea for a Committee on Undergraduate Policy again originated with a note from Compton. Karl Compton to W. K Lewis, J. R. Loofbourow, 1 May 1948. In CES proceedings; Lewis Survey (n. 23 above), 69-78.

${ }^{54}$ On the faculty's reaction, see "Faculty records" (n. 12 above), Volume 22, 10/1/41 to 6/5/51, entries for 18 January 1950 forward. AC 1. MIT Institute Archives. 